\title{
Membangun Kesadaran Diri Generasi Muda akan Budaya Positif Melalui Penggunaan Media Sosial
}

\author{
El Chris Natalia \\ Universitas Katolik Indonesia Atma Jaya, Jakarta, Indonesia
}

\begin{abstract}
ABSTRAK
Perkembangan teknologi dan maraknya penggunaan media sosial dapat menimbulkan adanya pergeseran budaya yang tidak disadari individu. Untuk mencegah terjadinya pergeseran budaya ke arah yang negatif, di mana menghilangkan budaya asli atau budaya yang terkait dengan nilai-nilai dan norma-norma yang telah dianut, maka diperlukan sebuah upaya untuk membangun kesadaran dalam diri individu mengenai perkembangan teknologi pada media sosial. Berdasarkan hal ini, maka diadakanlah kegiatan sosialisasi dan pelatihan dengan tema umum, yaitu "Digital Challenge, Social Media, and Journalism". Kegiatan ini ditujukan bagi generasi muda Sumba. Tujuan dari sosialisasi dan pelatihan ini adalah untuk memberikan pemahaman generasi muda di Sumba mengenai dampak media sosial dan membangun kesadaran diri generasi muda untuk menjaga budaya yang positif melalui penggunaan media sosial. Sosialisasi dan pelatihan ini diadakan di Kantor Bupati Sumba Barat, NTT dan dihadiri oleh 100 peserta. Kegiatan sosialisasi dan pelatihan berjalan dengan lancar dan peserta antusias untuk saling berbagi dan berdiskusi mengenai penggunaan media sosial.
\end{abstract}

Kata kunci: kesadaran diri; perkembangan teknologi; media sosial; generasi muda

\begin{abstract}
Technological developments and the widespread use of social media can lead to cultural shifts that individuals are not aware of. To prevent a negative cultural shift, where the elimination of the original culture or culture associated with the values and norms that have been adopted, an effort is needed to build awareness in individuals about technological developments on social media. Based on this, socialization and workshop were held with a theme "Digital Challenge, Social Media, and Journalism". This activity is intended for the young generation of Sumba. The purpose of this socialization and workshop is to provide an understanding of the younger generation in Sumba about the impact of social media and build self-awareness to maintain a positive culture through social media. This socialization and workshop were held at the Regent's Office of West Sumba, NTT and was attended by 100 participants. The socialization and workshop went well and the participants were enthusiastic about sharing and discussing the use of social media.
\end{abstract}

Keywords: self-awareness; technological development; social media; the younger generation

\section{PENDAHULUAN}

Perkembangan teknologi pada media sosial membuat berbagai media dan informasi langsung dapat diakses melalui satu platform. Boyd (dalam Nasrullah, 2015) mendefinisikan media sosial sebagai kumpulan perangkat lunak yang memungkinkan individu dan komunitas untuk 
berkumpul, berbagi, berkomunikasi, dan dalam situasi tertentu bisa saling berkolaborasi atau bermain. Media sosial tidak hanya digunakan untuk mendistribusikan informasi yang bisa dikreasikan oleh pemilik akun (users) itu sendiri, tetapi juga memiliki dasar sebagai portal untuk membuat jaringan pertemanan secara virtual dan medium untuk berbagi data, seperti audio atau video (Nasrullah, 2015). Kehadiran media sosial menjadikan masyarakat bisa dengan bebas dan mudahnya mendapatkan informasi apapun tanpa batasan waktu, tempat dan sumber.

Hootsuite dan We Are Social melakukan survei tiap tahunnya mengenai media sosial. Berdarkan hasil survei yang dilakukan pada tahun 2019 di Indonesia, total pengguna aktif media sosial mencapai 150 juta. Jumlah pengguna media sosial ini mencapai 56\% dari jumlah total penduduk Indonesia (websindo.com, 2019). Namun, hasil survei pada tahun 2020 menunjukkan total pengguna aktif media sosial di Indonesia adalah 160 juta dimana jumlah pengguna media sosial mencapai 59\% dari jumlah total penduduk Indonesia. Berdasarkan data ini, dapat disimpulkan terdapat peningkatan jumlah pengguna media sosial di Indonesia sebesar 12 juta (+8.1\%) antara April 2019 dan Januari 2020 (datareportal.com, 2020). Selain itu, hasil survei juga menunjukkan rata-rata durasi penggunaan media sosial setiap harinya adalah 3 jam 26 menit (datareportal.com, 2020). Peningkatan penggunaan media sosial ini menjadi perhatian bahwa media sosial telah menjadi bagian dalam kehidupan masyarakat dan tidak menutup kemungkinan akan semakin meningkat lagi penggunaannya di masa yang akan datang.

Berbagai penelitian mengenai penggunaan media sosial juga telah dilakukan. Terdapat dua penelitian yang menunjukkan peran dan dampak dari media sosial bagi masyarakat. Penelitian pertama adalah penelitian yang dilakukan oleh Rahmawati (2018) mengenai "Penerimaan Masyarakat terhadap Pesan Kesehatan melalui Media Internet" menunjukkan bahwa Whatsapp menjadi media sosial peringkat pertama penyampai pesan kepada masyarakat. Sikap masyarakat terhadap pesan kesehatan yang mereka terima secara mayoritas adalah kadang-kadang mengikuti dan meneruskan pesan tersebut. Penerimaan masyarakat terhadap pesan kesehatan melalui media sosial sebagian besar termasuk pada kelompok negotiated position dimana khalayak mampu menerima ideologi yang dominan dan akan bergerak menindaklanjuti dengan beberapa pengecualian dan sebagian kecil termasuk pada kelompok dominant hegemony position, yaitu terjadi ketika setiap individu bertindak terhadap sebuah kode sesuai apa yang dirasakan mendominasi untuk memiliki kekuatan lebih pada kode lainnya.

Penelitian kedua terkait media sosial dapat dilihat dari penelitian yang dilakukan oleh Khairil et al. (2019) dengan judul "Efek Ketergantungan Remaja K-Popers terhadap Media Sosial di Kota Palu". Hasil penelitian menunjukkan terdapat pengaruh antara mengakses informasi KPop terhadap tingkat ketergantungan penggunaan media sosial pada remaja. Inti dari penelitian ini adalah mengusulkan kebijakan baru tentang pendekatan edukatif terkait 
pemanfaatan media sosial di Kota Palu sehingga pengguna dapat lebih selektif dan mampu mengontrol diri dalam penggunaan media sosial.

Dari kedua hasil penelitian tersebut dapat dilihat bahwa media sosial memiliki berbagai peranan dan memberikan berbagai dampak dalam kehidupan masyarakat. Semakin sering orang menggunakan media sosial, maka akan semakin besar juga ketergantungannya akan penggunaan media sosial. Penyebaran pesan bisa dilakukan di media sosial, seperti Whatsapp, Line, Instagram, Facebook dan lainnya. Cara dan pola masyarakat dalam menerima dan mengolah pesan yang disebarkan di media sosial menjadi sorotan. Selain itu, ketergantungan akan media sosial juga merupakah hal penting lainnya yang harus diperhatikan oleh masyarakat. Dampak yang muncul karena media sosial bisa sangat beragam.

Perkembangan teknologi dan maraknya penggunaan media sosial memberikan berbagai dampak dalam kehidupan masyarakat, salah satunya adalah terjadinya pergeseran budaya. Budaya tidak hanya bicara mengenai apa yang tampak di mata, seperti pakaian adat, umur, bahasa, jenis kelamin, dan lainnya, tetapi juga yang tidak tampak di mata, antara lain kepercayaan, nilai-nilai yang dianut tiap individu, dan lain-lain. Untuk mencegah terjadinya pergeseran budaya ke arah yang negatif, di mana menghilangkan budaya asli atau budaya yang terkait dengan nilai-nilai dan norma-norma yang telah dianut, maka diperlukan sebuah upaya untuk membangun kesadaran dalam diri individu mengenai perkembangan teknologi pada media sosial.

Budaya itu sendiri bahkan dapat diciptakan melalui media sosial. Nasrullah (2015) mengatakan bahwa internet merupakan ruang di mana budaya diproduksi, didistribusikan, dan dikonsumsi. Berdasarkan hal inilah dapat dikatakan bahwa media sosial bisa menajdi wadah untuk budaya siber dan melalui media sosial juga dapat diketahui artefak budaya siber itu berkembang. Ini menunjukkan bahwa budaya dapat muncul di dunia maya yang juga tidak menutup kemungkinan akan menggeser budaya lokal atau budaya positif yang tertanam di masyarakat jika pengguna tidak memahami penggunaan media sosial dengan bijak.

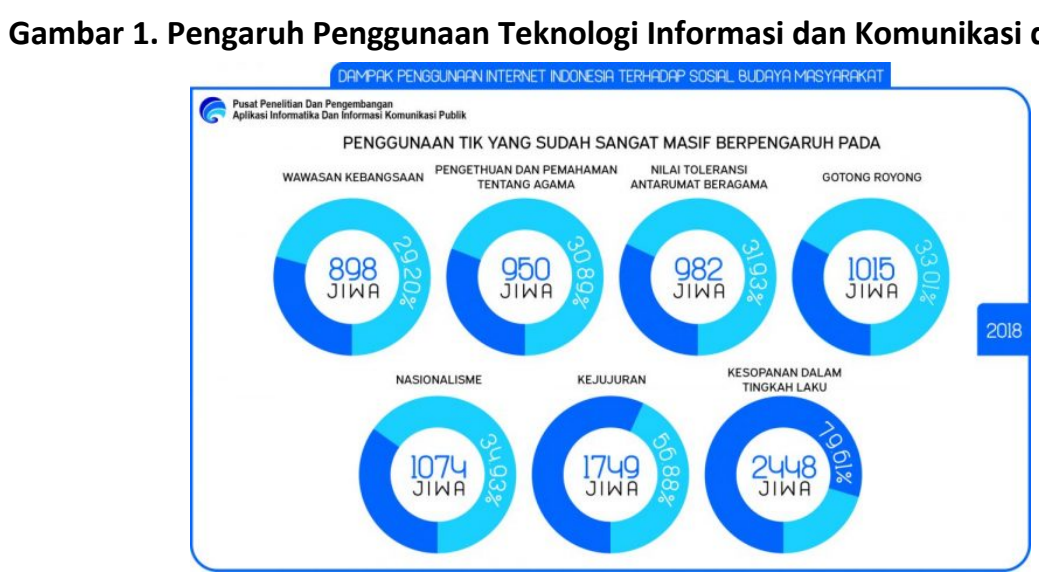

Sumber: Rizkinaswara (2019) 
Gambar 2. Sikap Ketika Menerima Konten/Informasi Negatif DAMPAK PENGGUNAPN INTERNET INDONESIA TERHADFP SOSPL BUDAYAMASYARAKAT

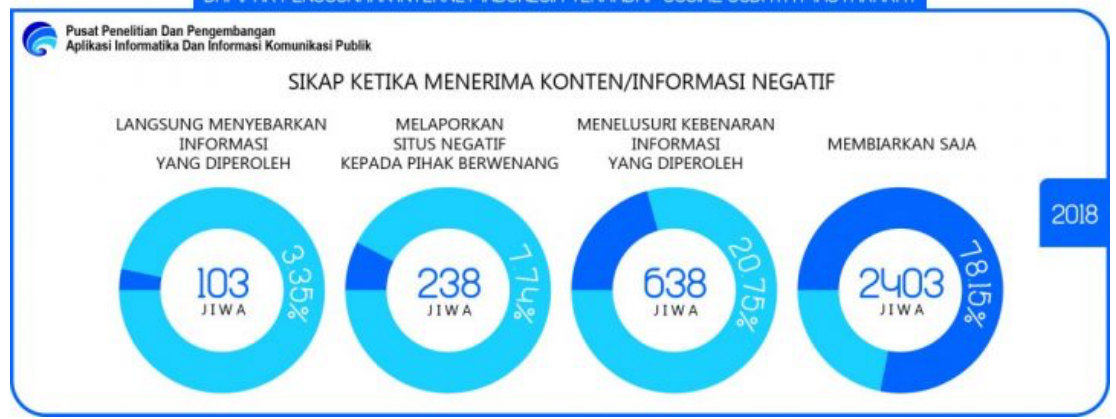

Sumber: Rizkinaswara (2019)

Pada gambar 1, berdasarkan Hasil Survei yang dilakukan oleh Puslitbang Aptika-IKP Kemkominfo pada tahun 2018 mengenai Penggunaan TIK dan implikasinya terhadap Sosial Budaya Masyarakat, dapat dilihat bahwa terjadi perubahan baik positif maupun negatif akibat penggunaan teknologi informasi dan komunikasi (TIK) dan internet. Persentase paling banyak terjadi pada kesopanan dalam tingkah laku, kejujuran dan gotong royong (Rizkinaswara, 2019). Pada gambar 2, hasil survei menunjukkan masih ada orang yang peduli terhadap penyebaran informasi negatif dengan menelusuri kebenarannya dan melaporkannya. Namun masih ada juga yang bersikap kurang aktif dengan membiarkannya saja dengan persentase yang paling besar. Bahkan, masih ada sejumlah kecil orang yang langsung menyebarkan informasi negatif begitu saja. Hasil survei ini dapat menjadi rujukan bagi akademisi Ilmu Komunikasi untuk terus membangun literasi media sosial di Indonesia. Hasil survei tersebut juga menunjukkan berbagai perubahan tingkah laku masyarakat sebagai pengguna media sosial. Media sosial dapat memberikan berbagai informasi dan pengetahuan bagi penggunanya, namun juga mampu menggeser budaya positif yang ada dalam diri pengguna.

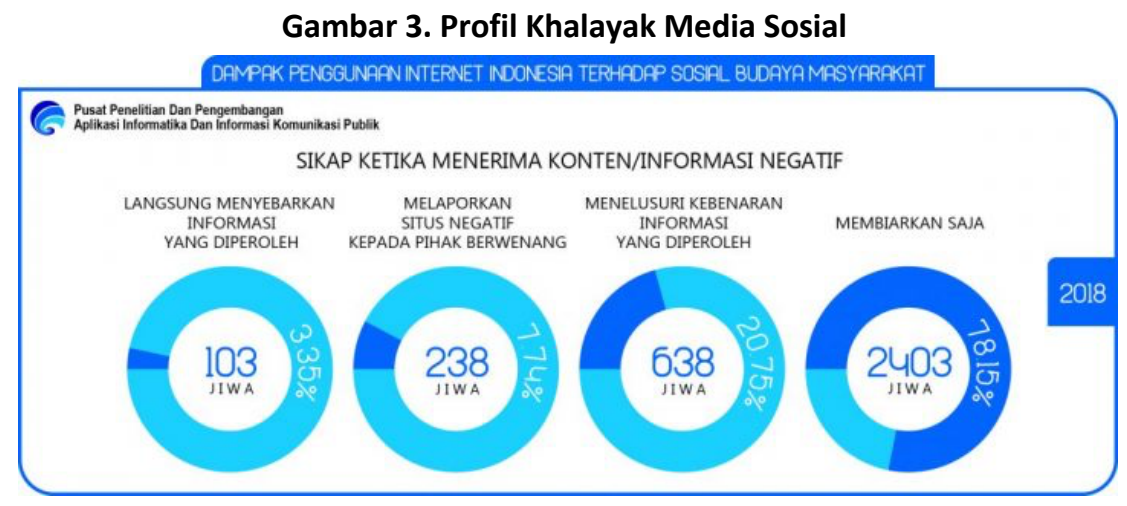

Sumber: websindo.com (2019)

Generasi muda merupakan generasi yang paling dekat dengan media sosial. Dikutip dari kumparan.com (2018), rentang usia pemuda adalah kelompok masyarakat dalam rentang usia 15-32 tahun (UNDP Youth Strategy, 2014-2017:47). Berdasarkan UU No.40 2009 tentang Kepemudaan Pasal 1 Ayat 1, rentang usia 16-30 tahun termasuk dalam rentang usia pemuda. Berdasarkan survei yang dilakukan oleh Hootsuite dan We Are Social pada Januari 2019 
(gambar 3), terlihat bahwa pengguna media sosial paling banyak adalah pada usia 18-34 tahun, baik pria maupun wanita. Kesadaran diri dari generasi muda sebagai penerus bangsa ini perlu dibangun agar mereka dapat melestarikan budaya lokal dan membangun budaya yang positif melalui penggunaan media sosial.

Pengguna media sosial juga harus menyadari perilakunya dengan memahami budaya yang berbeda-beda di tiap tempat. Tidak adanya kesadaran tersebut seringkali juga menimbulkan masalah. Dikutip dari travel.detik.com (2018), ada kasus perilaku yang tidak baik dari wisatawan pria dan wanita yang berkunjung ke objek wisata Kete Kesu, Toraja. Kedua wisatawan ini berpose dengan cara memegang tulang sebagai gitar dan seolah menginjak tengkorak. Aksi yang dilakukan wisatawan tersebut menjadi viral di media sosial. Menurut Kadis Pariwisata dan Budaya Toraja Utara, Harly Patriatno, tindakan yang dilakukan wisatawan tersebut melecehkan adat dan budaya Toraja dan sangat tidak bermoral. Padahal, sudah ada aturan atau kode etik bagi para wisatawan yang akan berkunjung atau mendatangi objek wisata untuk berpakaian sopan, berkelakuan baik serta mematuhi adat istiadat yang berlaku di Toraja. Perilaku yang ditunjukkan oleh wisatawan tersebut bukanlah perilaku yang baik untuk diperlihatkan ke masyarakat melalui media sosial. Dalam mengunggah konten di media sosial, pengguna juga harus memperhatikan etika dan norma yang berlaku di dunia virtual dengan tidak melupakan aturan, etika dan norma yang juga berlaku secara nyata.

Kegiatan sosialisasi dan pelatihan untuk membangun kesadaran masyarakat akan budaya positif melalui penggunaan media sosial dilakukan di Pulau Sumba yang merupakan salah satu pulau di Provinsi NTT. Wilayah Provinsi Nusa Tenggara Timur, termasuk dalam kawasan circum-pasifik. Pulau Sumba dan beberapa pulau lainnya, seperti Pulau Sabu dan Pulau Timor terbentuk dari dasar laut yang terangkat ke permukaan (nttprov.go.id). Pulau Sumba, NTT saat ini telah menjadi salah satu destinasi wisata populer yang ada di Indonesia. Berdasarkan berita dari antaranews.com (2018), Kepala Dinas Pariwisata NTT, Marius Ardu Jelamu mengatakan bahwa Pulau Sumba merupakan satu dari berbagai tempat wisata yang memiliki pesona indah di provinsi yang berbasiskan kepulauan ini. Tren minat wisatawan sudah beralih ke Pulau Sumba, setelah tujuan utama ke Labuan Bajo. Objek-objek wisata unggulan mulai banyak bermunculan di Pulau Sumba. Pada travel.kompas.com (2019) diberitakan mengenai enam destinasi wisata di Pulau Sumba dengan pesona keindahannya, yaitu Bukit Wirinding, Air Terjun Wai Marang, Danau Weekuri, Air Terjun Matayangu, Puru Kambera, dan Taman Nasional Laiwangi Wanggameti. Tempat-tempat wisata ini bahkan sudah bermunculan di media sosial. Banyak wisatawan yang mengunggah keindahan objek wisata yang ada di Sumba. Media sosial menjadi wadah untuk memperkenalkan tempat-tempat wisata.

Sebelumnya, pada tahun 2018 pemateri juga pernah memberikan pelatihan mengenai literasi media sosial di daerah Sumba Barat. Di tahun 2019, pemateri melakukan survei singkat dan observasi terlebih dulu ke beberapa penduduk lokal di Sumba yang dibantu oleh rekan-rekan dari English Goes to Kampung (EGK). Hasilnya menunjukkan bahwa media sosial sudah mulai 
masuk dalam kehidupan masyarakat Sumba, khususnya remaja dan anak muda yang tinggal di perkotaan di kabupaten. Menurut tim EGK, anak-anak muda di Sumba masih sangat minim pengetahuan dan pemahaman akan penggunaan media sosial dengan bijak. Saat ini diperlukan pemahaman mengenai penggunaan media sosial bagi generasi muda di Sumba. Oleh karena itu, berdasarkan hasil diskusi, disepakati untuk diadakan sosialisasi dan pelatihan dengan tema mengenai "Digital Challenge, Social Media, and Journalism" yang dibagi menjadi beberapa topik. Pada artikel ini, topik sosialisasi dan pelatihan yang dibawakan oleh penulis sebagai pemateri adalah "Membangun Kesadaran Diri Generasi Muda akan Budaya Positif Melalui Penggunaan Media Sosial". Kegiatan sosialisasi dan pelatihan yang berfokus pada media sosial ini dilakukan juga karena mengingat ada berbagai dampak yang dapat muncul akibat penggunaan media sosial.

Sosialisasi dan pelatihan yang diadakan di Sumba tersebut bertujuan untuk memberikan pengenalan dan pemahaman mengenai perkembangan media sosial dan pengaruhnya dalam kehidupan generasi muda di Sumba. Tujuan lainnya adalah untuk membangun kesadaran dalam diri generasi muda untuk menjaga budaya yang positif melalui penggunaan media sosial. Penggunaan media sosial dapat memungkinkan munculnya pergeseran budaya. Oleh karena itu, diharapkan kegiatan ini dapat memberikan manfaat dalam membantu generasi muda di Sumba untuk membangun kesadaran diri dan menjadi lebih waspada akan dampak negatif terkait pergeseran budaya yang dapat timbul akibat perkembangan teknologi pada media sosial. Generasi muda diharapkan dapat bijak dalam menggunakan media sosial.

\section{METODE PELAKSANAAN}

Sebelum melaksanakan sosialisasi dan pelatihan, sekitar tiga bulan sebelumnya, pemateri, tim pemateri lainnya, dan tim dari English Goes to Kampung (EGK) melakukan survei singkat mengenai perilaku anak muda akan penggunaan media sosial. Survei kecil ini dibantu oleh rekan-rekan dari EGK. EGK merupakan sebuah lembaga atau organisasi nonprofit yang memberikan pelatihan bahasa Inggris dan kegiatan sosial lainnya di Sumba. Melalui EGK, informasi mengenai sosialisasi dan pelatihan dapat disebarkan dengan mudahnya ke berbagai daerah di Sumba. Survei tersebut dilakukan dengan tujuan agar materi dan pelatihan yang diberikan sesuai dengan kebutuhan dari anak-anak muda di Sumba. Setelah didapatkan hasil survei, pemateri segera membuat materi dengan mengumpulkan data-data dan teori-teori terkait media sosial. Pemateri juga menyiapkan beberapa contoh video mengenai dampak media sosial yang dapat mengubah pola pikir, tingkah laku atau budaya seseorang. Setelah pemateri dan tim tiba di Waikabubak, Sumba Barat, NTT, kami bertemu dengan tim EGK satu hari sebelum pelaksanaan untuk briefing kegiatan dan mengecek kembali peralatan yang akan digunakan. Selain dengan EGK, pelaksanaan kegiatan ini juga melibatkan kerja sama dari Komisi Kepemudaan Weetabula Sumba dan Pemerintah Daerah Sumba Barat. 
Kegiatan sosialisasi dan pelatihan bertemakan tentang "Digital Challenge, Social Media, and Journalism" ini diadakan pada 11-14 September 2019 bertempat di Kantor Bupati Sumba Barat, Sumba, NTT. Target khalayak pada pelatihan ini adalah remaja dan pemuda di Sumba. Jumlah peserta yang hadir saat kegiatan ini sejumlah 100 orang. Peserta yang hadir beragam, mulai dari pelajar, mahasiswa hingga karyawan. Peserta tidak hanya datang dari Sumba Barat, tetapi juga dari kabupaten-kabupaten lain di Sumba. Peralatan yang digunakan untuk kegiatan sosialisasi dan pelatihan ini, antara lain infocus projector, speaker, mic, beberapa gulung kertas flipchart, spidol, dan lainnya. Pembicara menyiapkan materi dan memberikan beberapa contoh video yang ditampilkan pada slide materi. Bahkan pada hari pelaksanaan, tim membantu pengecekan terhadap peralatan yang diperlukan oleh band akustik untuk menemani jalannya kegiatan melalui pertunjukan musik.

Sosialisasi dan pelatihan dengan topik "Membangun Kesadaran Diri Generasi Muda akan Budaya Positif Melalui Penggunaan Media Sosial" ini dibagi menjadi beberapa sesi. Sesi pertama adalah paparan teoretis dan penjelasan sederhana mengenai perkembangan, dampak, dan tantangan yang muncul karena media sosial di Indonesia. Pembahasan tentang munculnya pergeseran budaya di masyarakat masuk dalam sesi pemaparan teoretis ini. Sesi kedua adalah belajar menyaring informasi yang diperoleh di media sosial dan menyebarkan konten atau pesan positif dan bermanfaat melalui media sosial. Pemateri juga memberikan contoh nyata dan belajar membedakan antara informasi hoax dan bukan hoax, mengajarkan untuk melakukan pengecekan data sebelum menyebarkan data ke orang lain dan/atau menerima untuk diri sendiri, serta berlatih memilih dalam mengkonsumsi konten yang tepat untuk media sosial. Sesi terakhir adalah sesi berbagi (sharing), diskusi dan tanya-jawab.

\section{HASIL DAN PEMBAHASAN}

Kegiatan pengabdian kepada masyarakat yang dilakukan di Sumba dengan tema "Digital Challenge, Social Media, and Journalism" dibuka dan dihadiri oleh Wakil Bupati Sumba Barat, yaitu Bapak Marthen Ngailu Toni. Kata sambutan juga diberikan oleh Ketua Yayasan English Goes to Kampung, Ibu Sri Wahyuningsih, Perwakilan dari Komisi Kepemudaan Weetabula Sumba, Romo Willy, dan perwakilan dari tim Prodi Ilmu Komunikasi Universitas Katolik Indonesia Atma Jaya, Ibu Lisa Esti Puji Hartanti. 


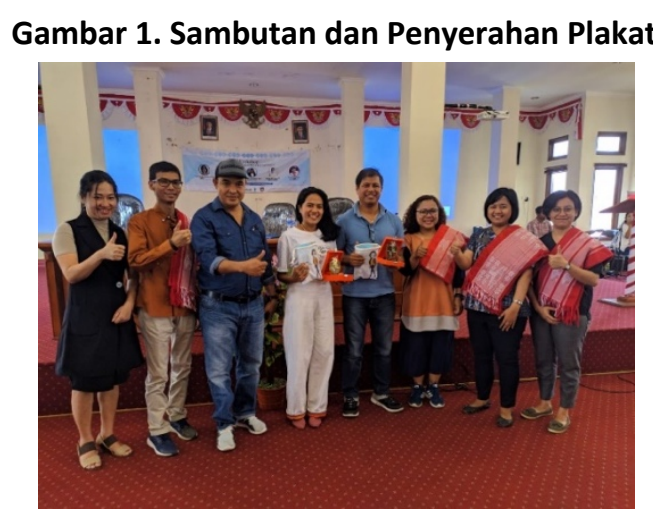

Sumber: dokumentasi pemateri

Pada bagian kegiatan dengan topik "Membangun Kesadaran Diri Generasi Muda akan Budaya Positif Melalui Penggunaan Media Sosial", sesi dimulai dengan paparan teoretis. Pemateri memberikan paparan mengenai perkembangan media sosial di Indonesia dengan menyajikan data-data yang diperoleh dari berbagai sumber dokumen. Selain itu, pemateri juga menjelaskan tantangan yang akan dihadapi oleh generasi muda karena media sosial. Tantangan yang ada salah satunya adalah pergeseran budaya. Pemateri juga menjelaskan mengenai dampak-dampak yang dapat muncul dari penggunaan media sosial. Dalam hal ini, pemateri mengajarkan bahwa budaya lokal dan budaya yang positif harus tetap dijaga dan bahkan peserta bisa menjadi pencipta konten untuk menyebarkan budaya lokal Indonesia dan budaya positif. Contoh-contoh juga diberikan melalui pemutaran video. Pemutaran video (audiovisual) akan memudahkan peserta untuk menangkap pesan yang disampaikan. Saat pemutaran video, peserta terlihat antusias dan memperhatikan dengan baik. Pemateri juga memberikan informasi mengenai etika bermedia sosial. Di sini pemateri menjelaskan bahwa media sosial bukan ranah pribadi meskipun media sosial dapat diproteksi dan dibatasi hanya untuk teman-teman dekat. Pemateri mengingatkan kepada peserta bahwa apa yang diunggah di media sosial akan masuk dalam rekam jejak digital. Bahkan, bisa dengan mudahnya pengguna media sosial lainnya langsung mendokumentasikan (rekam atau screenshot) lalu menyebarkan konten yang kita unggah di media sosial walaupun tidak lama kemudian kita menghapus konten tersebut. Pemaparan teoretis ini berguna untuk memberikan pengetahuan dasar dan pemahaman bagi peserta mengenai media sosial. Hal ini penting dilakukan agar membentuk pola pikir dan perilaku yang baik bagi peserta, khususnya mereka yang menggunakan media sosial.

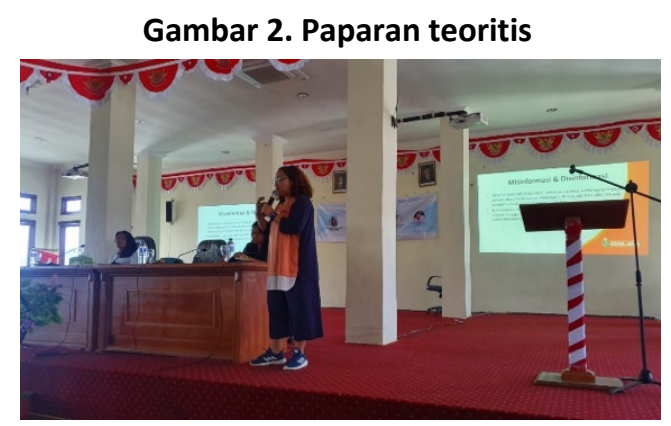

Sumber: dokumentasi pemateri 
Setelah itu, pada sesi belajar untuk membedakan informasi hoax dan bukan hoax serta melakukan pengecekan data, peserta terlihat lebih antusias untuk belajar. Pemateri memberikan informasi kepada peserta mengenai istilah misinformasi dan disinformasi. Pemateri juga mengajarkan untuk menggunakan anti hoax search engine dari turnbackhoax.id dan peserta bisa melaporkan melalui portal tersebut jika menemukan bahwa data yang mereka dapatkan adalah hoax. Begitu juga mengenai gambar atau foto. Pemateri mengajarkan pengecekan untuk foto dapat dilakukan melalui google image dengan men-drag atau unggah foto atau copy-paste URL foto yang ingin dicek. Peserta mengakui bahwa mereka baru mengetahui bahwa ada cara untuk mengecek informasi hoax seperti ini. Pemateri mengajarkan peserta untuk check and re-check juga ke portal-portal berita yang dapat dipercaya dan jangan hanya berfokus pada satu portal berita. Pemateri memberikan contoh dari sebuah gambar untuk mengecek apakah gambar tersebut merupakan gambar yang bisa dipercaya dan sesuai dengan konteks pesan yang dibagikan melalui media sosial. Sesi ini penting bagi para peserta karena berdasarkan survei singkat, masih ada orang-orang yang dengan mudah dan cepatnya percaya pada pesan berantai yang diberikan (biasanya melalui aplikasi Whatsapp) tanpa mengeceknya terlebih dulu. Minimnya pengetahuan dalam mengkonsumsi informasi yang benar ini menjadi perhatian bagi pemateri untuk menyadarkan peserta akan bahaya atau dampak negatif dari pesan hoax. Masyarakat pengguna ponsel pintar dan juga media sosial saat ini harus menjadi masyarakat yang cerdas dalam menyebarkan dan mengkonsumsi berita dari berbagai media.

Sesi berbagi (sharing), diskusi dan tanya-jawab ternyata menjadi sesi yang dinantikan juga oleh peserta. Pada sesi ini, banyak peserta yang antusias mengajukan pertanyaan dan juga menceritakan pengalaman pribadinya mengenai media sosial. Pertanyaan yang diajukan, antara lain bagaimana cara untuk mengajarkan ke orang lain, khususnya keluarga mengenai penggunaan media sosial, bagaimana cara memulai agar lebih bijak menggunakan media sosial, bagaimana cara untuk menghindari hoax yang dikirimkan melalui media sosial (Whatsapp), bagaimana menggunakan media sosial yang tepat untuk memperkenalkan budaya lokal ke masyarakat di luar Sumba, bagaimana bisa membatasi waktu dalam bermain media sosial, dan lainnya. Pertanyaan tidak hanya datang dari remaja atau pelajar. Pertanyaan juga diajukan oleh seorang Romo yang merupakan perwakilan dari Komisi Kepemudaan Weetabula Sumba. Ternyata maraknya penggunaan media sosial menjadi perhatian di organisasi ini. Banyak anak muda yang salah langkah dalam menggunakan media sosial dan tak jarang juga banyak yang menjadi korban hoax. Menurutnya, banyak orang yang mengira bahwa media sosial adalah milik pribadi sehingga bisa menggunakan dan mengisi konten dengan bebas. Selain itu, tidak jarang orang melupakan waktu saat bermain media sosial. Pada sesi tanya-jawab ini, pemateri memberikan jawaban dan masukkan bagi penanya yang disesuaikan dengan konteks yang terjadi secara nyata. Mengatur waktu dengan sebaiksebaiknya dan menyusun jadwal dengan baik dapat membatasi penggunaan media sosial. 
Pemateri mengingatkan bahwa kecanduan media sosial dapat memberikan dampak yang negatif, baik untuk fisik maupun psikis.

Saat sesi berbagi (sharing), peserta juga masih terlihat antusias. Beberapa dari peserta membagikan pengalamannya dan kemudian didiskusikan bersama. Dalam hal ini pemateri juga turut membantu memberikan masukkan atau solusi terhadap permasalahan yang diceritakan oleh peserta. Ada suatu permasalahan yang cukup menarik yang dibagikan oleh peserta yang adalah pelajar. Pelajar ini menceritakan bahwa media sosial Facebook sudah sangat mempengaruhi kehidupan sehari-hari ibunya. Sejak mengenal dan menggunakan Facebook, ibunya lebih sering menghabiskan waktunya dengan bermain Facebook bahkan melebihi anaknya. Pelajar ini juga bercerita apa saja yang dilakukan ibunya, seperti memasak makanan akan diunggah ke Facebook. Bagi kebanyakan orang, ini bisa menjadi sebuah cerita yang lucu. Namun jika dilihat dari dampaknya, perilaku seperti ini akan memberikan dampak yang negatif, tidak hanya bagi diri orang itu sendiri, tetapi juga orang-orang di sekitarnya. Orang di sekitarnya dalam hal ini adalah keluarganya. Pelajar ini kemudian menanyakan hal apa yang bisa dilakukannya untuk menyadarkan ibunya mengenai penggunaan media sosial. Menjawab pertanyaan dari pelajar tersebut, pemateri menyampaikan bahwa untuk lebih sadar dalam menggunakan media sosial, semua dimulai dari diri sendiri. Tiap individu perlu memahami terlebih dulu mengenai media sosial, termasuk mengenai waktu atau durasi penggunaan yang tepat, dampak positif dan negatif, etika dan norma, manfaat yang bisa diperoleh dari media sosial, dan lain sebagainya. Pemahaman yang baik harus diikuti dengan realisasi yang dilakukan oleh individu tersebut dalam kehidupannya sehari-hari. Dari pemahaman dan pengetahuannya tersebut, maka individu dapat menyebarkannya ke orangorang di sekitarnya. Pemberian contoh yang tepat juga dapat membantu untuk membangun kesadaran seseorang terkait bijak dalam menggunakan media sosial.

\section{SIMPULAN}

Media sosial tidak selalu memberikan efek yang buruk atau negatif ke para penggunanya. Media sosial juga bisa memberikan dampak positif ke penggunanya jika digunakan dengan kreatif dan bijak. Pemateri mengajak para peserta untuk memperkenalkan dan mempromosikan budaya lokal Sumba ke masyarakat luas. Budaya berupa hasil karya/kerajinan lokal dan keindahan tempat-tempat wisata yang ada di Sumba dapat diperkenalkan melalui media sosial. Terlebih, Pulau Sumba telah menjadi destinasi wisata lokal dan internasional dari Provinsi NTT. Bahkan, dikutip dari antaranews.com (2018), majalah Focus dari Jerman menobatkan Pulau Sumba sebagai pulau terindah di dunia (The Best Beautiful Island in The World). Masyarakat dan pengrajin lokal di Pulau Sumba bisa menggunakan media sosial untuk memasarkan produknya. 
Tantangan teknologi, khususnya dalam media sosial itu sendiri akan selalu ada. Tantangan tersebut dapat berupa perubahan atau pergeseran budaya, munculnya kejahatan siber, terpaan informasi yang begitu beragam dan mudah untuk diakses, pola interaksi yang berubah, dan lainnya. Oleh karena itu, mengenal lebih jauh tentang media sosial dan memahami hal-hal yang boleh dan tidak boleh dilakukan dalam bermedia sosial merupakan salah satu jawaban dalam menghadapi tantangan di dunia digital tanpa merugikan diri sendiri dan orang lain. Media sosial justru dapat digunakan untuk memperkenalkan dan mempromosikan budaya lokal, menunjukkan kreativitas yang bermanfaat, dan interaksi yang positif. Budaya, perilaku dan pengetahuan positif yang kuat dalam diri individu dapat menjadi dasar atau pijakan saat seseorang menggunakan media sosial.

Paparan teoretis yang diberikan pemateri diharapkan dapat memberikan wawasan baru dan menjadi bekal bagi peserta dalam menghadapi tantangan media digital, khususnya media sosial. Peserta diharapkan mampu mengenal dan memahami fungsi dan manfaat media sosial. Dampak yang tidak baik dari penggunaan media sosial dapat dihindari dengan penggunaan yang bijak dan tepat. Masyarakat perlu mengingat budaya lokal dan positif yang menjadi kekhasan dari Indonesia. Peserta diharapkan tidak melupakan atau menyingkirkan budaya lokal dan budaya positif walaupun saat ini masyarakat tengah diterpa oleh media sosial yang semakin berkembang pesat. Sesi tanya-jawab juga menjadi sebuah kesempatan yang diberikan bagi peserta untuk menggali lebih dalam mengenai media sosial dan kesadaran masyarakat akan budaya positif.

Sesi berbagi (sharing) dan diskusi dilakukan dengan harapan peserta yang mengalami berbagai terpaan media sosial dapat mengerti dan memahami bagaimana harus bersikap dalam menjawab terpaan tersebut. Berbagai sudut pandang dan masukkan akan beberapa pengalaman yang diberikan akan memperkaya pengetahuan dari peserta, khususnya mereka sebagai pengguna media sosial. Peserta diharapkan dapat memahami bahwa untuk menjadi 'agen' literasi media sosial dimulai dari diri sendiri. Pemahaman dan pengetahuan yang baik mengenai media sosial yang ditanamkan dalam diri akan tercermin ke luar dan dapat menjadi panutan bagi orang sekitar. Mereka dapat memberikan pengaruh yang baik dan membangun kesadaran akan budaya positif bagi orang-orang di sekitar mereka untuk menggunakan media sosial dengan bijak.

Generasi muda sebagai generasi penerus bangsa diharapkan menjadi sosok yang bijak dalam bersikap dan terus melestarikan budaya bangsa yang positif. Generasi muda sebaiknya diajarkan untuk sadar akan banyaknya tantangan yang muncul akibat perkembangan media digital dan siap dalam menghadapi tantangan tersebut. Kegiatan sosialisasi dan pelatihan mengenai literasi media sosial ini diharapkan akan terus dilakukan di berbagai tempat untuk membuka wawasan dan kesadaran anak muda dalam bermedia sosial dengan baik. 


\section{DAFTAR PUSTAKA}

Aida, N. R. (2019, Juni 17). 6 Destinasi Wisata Di Sumba, Pesonanya Indah Tiada Tara. Kompas. https://travel.kompas.com/read/2019/06/17/220500627/6-destinasi-wisata-disumba-pesonanya-indah-tiada-tara?page=all

Hartawan, J. (2018, Maret 22). Soal Pose Wisatawan Melecehkan Makam Toraja: Tidak Bermoral. Detikcom. https://travel.detik.com/travel-news/d-3931228/soal-posewisatawan-melecehkan-makam-toraja-tidak-bermoral

Junus, H. (2018, Oktober 8). Over Supply Generasi Muda Indonesia dalam Tinjauan Strategi Demografi. Kumparan. https://kumparan.com/hakam-work/over-supply-generasimuda-indonesia-dalam-tinjauan-strategi-demografi-1539000922541119775

Khairil, M., Yusaputra, M. I., \& Nikmatusholeha. (2019). Efek Ketergantungan Remaja KPopers Terhadap Media Sosial di Kota Palu. Jurnal ASPIKOM, 4(1), 14. https://doi.org/10.24329/aspikom.v4i1.484

Lewokeda, A. (2018, Maret 18). Pulau Sumba Unggulan Baru Pariwisata NTT. ANTARANEWS.com. https://www.antaranews.com/berita/693848/pulau-sumbaunggulan-baru-pariwisata-ntt

Nasrullah, R. (2015). Media Sosial: Perspektif Komunikasi, Budaya, dan Sosioteknologi. Simbiosa Rekatama Media.

NTTprov.go.id. (2020, April 28). Kondisi Geografis Provinsi NTT. NTTprov.go.id. http://nttprov.go.id/2020/beranda/profil/kondisi-geografis/

Rahmawati, W. R. (2018). Penerimaan Masyarakat Terhadap Pesan Kesehatan Melalui Media Internet. Jurnal Komunikatif, 7(1), 95-105. https://doi.org/10.33508/jk.v7i1.1748

Rizkinaswara, L. (2019, Agustus 14). Dampak Penggunaan Internet Indonesia Terhadap Sosial Budaya Masyarakat. Kominfo.go.id. https://aptika.kominfo.go.id/2019/08/dampakpenggunaan-internet-indonesia-terhadap-sosial-budaya-masyarakat/

We Are Social. (2020, Februari 18). Digital 2020: Indonesia. DataReportal. https://datareportal.com/reports/digital-2020-indonesia

Websindo. (2019). Indonesia Digital 2019: Media Sosial [Infographics]. Websindo. https://websindo.com/indonesia-digital-2019-media-sosial/ 